\title{
SYNTHESIS OF STABLE CANNABIDIOL (CBD) NANOPARTICLES IN SUSPENSION
}

\author{
SINTEZA STABILNIH NANODELCEV KANABIDIOLA (CBD) V \\ SUSPENZIJAH
}

\author{
Roman Štukelj ${ }^{1, \$}$, Metka Benčina ${ }^{2, \$ *}$, Mattia Fanetti ${ }^{3}$, Matjaž Valant ${ }^{3,4}$, \\ Mitja Drab ${ }^{2}$, Aleš Iglič ${ }^{2}$, Veronika Kralj-Iglič ${ }^{1}$ \\ ${ }^{1}$ Laboratory of Clinical Biophysics, Faculty of Health Sciences, University of Ljubljana, Zdravstvena 5, 1000 Ljubljana, Slovenia \\ ${ }^{2}$ Laboratory of Physics, Faculty of Electrical Engineering, Tržaška 25, 1000 Ljubljana, Slovenia \\ ${ }^{3}$ Materials Research Laboratory, University of Nova Gorica, Vipavska 13, 5000 Nova Gorica, Slovenia \\ ${ }^{4}$ Institute of Fundamental and Frontier Sciences, University of Electronic Science and Technology of China, Chengdu 610054, China
}

Prejem rokopisa - received: 2018-11-22; sprejem za objavo - accepted for publication: 2019-02-25

doi:10.17222/mit.2018.253

The reduction of cannabidiol (CBD) particle size in suspensions and maintenance of their stability is crucial for improved bioavailability and an increase in CBD's therapeutic effects. Here we report on a facile and cost-effective precipitation method for fast CBD nanonization. The characterization of the particle size in various suspensions was determined by dynamic light scattering (DLS), while scanning electron microscopy (SEM) analysis was performed to obtain the size and morphology of the dried CBD particles. The influence of the synthesis parameters (type and concentration of solvents and surfactants) on the size of the CBD particles in suspension were evaluated. By addition of the surfactants, the agglomeration of CBD nanoparticles (NPs) in suspension was prevented and the suspensions maintained stability for up to 9 months.

Keywords: cannabidiol, CBD, nanoparticles, precipitation

Zmanjšanje velikosti delcev kanabidiola (CBD) v suspenzijah in vzdrževanje njihove stabilnosti je ključnega pomena za izboljšanje biološke uporabnosti in povečanje terapevtskega učinka CBD. Predstavljena je sinteza nanodelcev kanabidiola $\mathrm{v}$ suspenziji z reakcijo obarjanja. Velikost delcev CBD v različnih suspenzijah smo izmerili z metodo dinamičnega sipanja svetlobe (DLS), medtem ko smo velikost in obliko posušenih nanodelcev CBD analizirali z vrstično elektronko mikroskopijo (SEM). Preučili smo vpliv sinteznih parametrov (vrsta in koncentracija topila, dodatek surfaktantov) na morfologijo CBD delcev. Z dodatkom surfaktantov smo preprečili aglomeracijo nanodelcev CBD ter supenzije ohranili stabilne do 9 mesecev.

Ključne besede: kanabidiol, CBD, nanodelci, metoda obarjanja

\section{INTRODUCTION}

The cannabis plant and its products contain an enormous variety of chemicals., ${ }^{1,2}$ Recent studies report more than 1200 different compounds, out of which there are about 140 terpens, about 50 flavonoids and more than 90 different cannabinoids/phytocannabinoids. ${ }^{3,4}$ The term cannabinoids represents a group of $\mathrm{C} 21$ or $\mathrm{C} 22$ terpenophenolic compounds found in Cannabis sativa L. ${ }^{5}$ $\Delta^{9}$-tetrahydrocannabinol $\left(\Delta^{9}\right.$-THC) and cannabidiol (CBD) are two major active components of the plant. ${ }^{6}$ They are the best known and most intensively studied cannabinoids, ${ }^{7}$ since it is indicated that they could be used in medicine. ${ }^{8}$ As it was found that $\Delta^{9}$-THC causes psychoactive side effects, CBD has recently become a subject of increased interest. The pharmacological actions of CBD show that it could be used for the treatment of epilepsy, ${ }^{9-12}$ central motor disorders, ${ }^{13,14}$ anxiety, ${ }^{15,16}$ nausea, diabetes, schizophrenia and demen-

\footnotetext{
*Corresponding author's e-mail:

metka.bencina@ijs.si

*Present address: Jožef Stefan Institute, Jamova 39, SI-1000 Ljubljana, Slovenia.

\$ The first and the second author corresponded equally to the work.
}

tia. ${ }^{17}$ Anti-inflammatory, ${ }^{18,19}$ anti-emetic ${ }^{20}$ and anti-psychotic $^{21}$ effects of CBD were also reported. At low doses CBD exhibited beneficial physiological effects, as an anti-oxidant and a neuroprotectant. ${ }^{22,23} \mathrm{CBD}$ was firstly isolated in 1940 by Adams et al., ${ }^{24}$ but its full structure was revealed about 20 years later. $^{25}$ To date, extensive studies have been performed on its chemical and biochemical properties, pharmacological and clinical effects. ${ }^{26,27}$

Cannabinoids are highly hydrophobic lipids, almost insoluble in water, ${ }^{28}$ but show good solubility in different organic solvents, such as methanol and ethanol..$^{29}$ It was believed that CBD's action could be mediated by its direct passing or insertion through biological membranes, but this scenario changed markedly in the early 1990s when Matsuda et al. ${ }^{30}$ cloned a cannabinoid receptor, therefore providing a mechanistic basis for cannabinoid's action. ${ }^{31}$ One of the major practical difficulties of cannabinoids is their extremely low water solubility, since drug solubility affects the drug uptake from the gastrointestinal tract, absorption into the bloodstream and reaching the target site in the human body. Since almost $80 \%$ of the human body consists of water, this correlates with CBD's low absorption rate and bioavail- 


\section{R. ŠTUKELJ et al.: SYNTHESIS OF STABLE CANNABIDIOL (CBD) NANOPARTICLES IN SUSPENSION}

ability, greatly hindering clinical use. ${ }^{32}$ Studies indicate that oral ingestion of oil-based hemp extracts has a bioavailability of between $4-20 \% .{ }^{33}$ This means that the majority of cannabinoids cannot enter the bloodstream. The fabrication of water-soluble cannabinoid products is therefore of significant importance.

In recent years, the role of nanotechnology in the pharmaceutical field received a lot of attention. It was reported that nanonization of the compound (i.e., reduction in size to below $1000 \mathrm{~nm}$ ) increased its surface area and solubility rate in an aqueous environment. ${ }^{34}$ Synthesis and applications of various nano-natural oils (e.g., nanosized curcumin) was already elaborated. ${ }^{35-37}$ Synthesis methods such as ultra-sonication, high-energy milling, spray freezing, high-pressure homogenization, ${ }^{38}$ etc. had been utilized to form nanosized pharmaceutical compounds. However, such methods often require highenergy input, complex operating conditions and have high production costs.

The nanonization of $\mathrm{CBD}$ is therefore crucial for its efficient medical utilization. Present research reports on the synthesis and characterization of nanosized CBD suspensions with the addition of surfactants. Surfactants are surface-active agents that exhibit a reduction in interfacial tension between the components in a material system and increase dispersion and preserve their coalescence. ${ }^{39,40}$ Mixtures of surfactants are commonly required to obtain desired hydrophilic-lipophilic Balance (HLB) - relative proportions of the hydrophilic and lipophilic parts of the surfactant molecule, ${ }^{41}$ which influences the surfactants' performance. Surfactants are critical components in pharmaceutical products, since they increase the solubility of drugs in aqueous media and improve drug absorption and penetration. ${ }^{42}$ In the present study, a mixture of GRAS (Generally Regarded as Safe) surfactants (Tween80/Span80) was used. Synthesis was performed with a simple and cost-effective precipitation reaction; CBD was dissolved in various solvents and precipitated by an antisolvent (deionized water). The morphology and size of precipitated CBD NPs in a suspension was assessed and aging of the suspension was observed in order to evaluate their stability.

\section{EXPERIMENTAL PART}

\subsection{Materials and methods}

Phyto-organic cannabidiol crystal isolate $(99.7 \%)$ was provided by Pharmahemp d.o.o., Slovenia. Ethanol (Sigma Aldrich, $96 \%$ ), acetone (Sigma Aldrich, $99.5 \%$ ), 2-propanole (Sigma Aldrich, $99.999 \%$ ), ethylene glycol (Fluka, $\geq 99.5 \%$ ), methanol (Sigma Aldrich, $\geq 99.5 \%$ ), dimethyl sulfoxide - DMSO (Sigma Aldrich, $\geq 99.5 \%$ ), Polyoxyethylenesorbitan monooleate Tween 80 (Sigma Aldrich, viscous liquid), Sorbitan monooleate - Span 80 (Sigma Aldrich, viscous liquid) and phosphotungistic acid hydrate - PTA (Sigma Aldrich, microscopic grade) were used in the experiments.

\subsection{Synthesis of nanosized CBD suspensions}

CBD nanosuspensions were synthesized by a facile antisolvent precipitation method. In a typical experiment, $10 \mathrm{mg}$ of CBD isolate was dissolved in $1 \mathrm{~mL}$ of solvent ethanol, acetone, methanol, 2-propanol, DMSO and ethylene glycol. In order to achieve complete dissolution, the solutions were ultrasonicated for $2 \mathrm{~min}$ and stirred with the magnetic stirrer for another $5 \mathrm{~min}$. A total of 15 $\mathrm{mL}$ of deionized water was added in the solutions during $10 \mathrm{~s}$ (seconds), while stirring at $500 \mathrm{~min}^{-1}$. Immediately after the addition of water, NPs precipitated and white emulsions were formed. In the experiments with surfactant as a stabilizer, the surfactants were dissolved in $15 \mathrm{~mL}$ of water and added to the CBD-ethanol solutions. The rate of Span 80/Tween 80 surfactants was 1:4 (w/\%). Different concentrations of surfactants were examined $0.1 \phi / \%, 0.25 \phi / \%, 0.5 \phi / \%, 0.75 \phi / \%$ and $1 \phi / \%$. Experiments with different CBD concentrations and solvent/water ratios were also performed with ethanol as a solvent (Table 1), since it is the prevalent solvent in the pharmaceutical industry. ${ }^{43}$ The prepared solutions were stored at $25{ }^{\circ} \mathrm{C}$ in order to evaluate their stability.

\subsection{Analysis of CBD nanosuspensions by DLS}

A particle size analysis of the CBD nano-suspensions with the Dynamic Light Scattering method (DLS) ZetasizerNano (Malvern, UK) was used to measure the size distribution of the CBD particles in suspensions immediately after the synthesis and after $24 \mathrm{~h}$. In a typical measurement the suspension was shaken by hand ten times and $1 \mathrm{~mL}$ was immediately pipetted into a glass cuvette. The average particle size (z) of the CBD in suspensions was calculated from the auto-correlation function. Zetasizer Software was used to analyse the results. All the measurements were performed at $20{ }^{\circ} \mathrm{C}$ using an angle of $173^{\circ}$ and a 633 -nm laser $5{ }^{\circ} \mathrm{C}$ three times in two parallel measurements.

\subsection{Analysis of dried CBD NPs by scanning electron microscopy (SEM)}

The morphology of the CBD NPs was analysed with a Jeol JSM 7001 TTLS scanning electron microscope. A $2 \%$ PTA solution with $\mathrm{pH}=7.4$ was used to fix the samples for the SEM analysis. A droplet of nanosuspension was placed on a cover slide and immediately covered with a droplet of PTA. The samples were left drying for $24 \mathrm{~h}$ at room temperature, coated with $\mathrm{Au} / \mathrm{Pd}$ (thickness $=8 \mathrm{~nm}$ ) and analysed. 


\section{RESULTS}

\subsection{Mean particle size of CBD determined by DLS}

A number of common solvents were tested in order to evaluate the effect of the solvent type on the size of the precipitated CBD NPs as presented in Table 1. The CBD NPs are soluble in all solvents, however, after the addition of an antisolvent (deionized water) the size of the precipitated NPs varied, as shown in Table 1. The difference between the NPs sizes ranges from $\approx 560 \mathrm{~nm}$ for methanol as a solvent to $\approx 830 \mathrm{~nm}$ for DMSO as a solvent immediately after the synthesis. In addition, the DLS analysis revealed that the size of the NPs increased with time; after $24 \mathrm{~h}$, the size of the CBD NPs prepared in 2-propanol increased from $\approx 760 \mathrm{~nm}$ to $\approx 2620 \mathrm{~nm}$. The lowest increase of the NPs size after $24 \mathrm{~h}$ was observed for the sample prepared in ethylene glycol (from $\approx 670 \mathrm{~nm}$ to $\approx 1085 \mathrm{~nm}$ ).

A detailed analysis of the variation of the synthesis parameters on the CBD NPs' size was performed by using ethanol as precursor for CBD NP formation. DLS analysis showed that the size of the CBD NPs in ethanol decreases with increasing volume of antisolvent. The CBD NP size measured immediately after the synthesis was $\approx 3080 \mathrm{~nm}$ and $\approx 530 \mathrm{~nm}$ for the water volume of 2 $\mathrm{mL}$ and $30 \mathrm{~mL}$, respectively (Table 1). The DLS analysis also revealed the effect of CBD concentration dissolved in ethanol on the mean NP size: a higher CBD concentration leads to larger CBD NPs (from $\approx 550 \mathrm{~nm}$ for
$1 \mathrm{mg} / \mathrm{mL} \mathrm{CBD}, t=0$ to $\approx 745 \mathrm{~nm}$ for $20 \mathrm{mg} / \mathrm{mL} \mathrm{CBD}$, $t=0$ ). The same effect was observed $24 \mathrm{~h}$ after synthesis; the fastest growth of CBD NPs was detected for a CBD concentration of $20 \mathrm{mg} / \mathrm{mL}$ (the size increased from $\approx 745 \mathrm{~nm}$ to $\approx 2010 \mathrm{~nm}$ ), while the lowest increase of NP size was detected for a CBD concentration of $1 \mathrm{mg} / \mathrm{mL}$ (the size increased from $\approx 550 \mathrm{~nm}$ to $\approx 870 \mathrm{~nm}$ ).

The CBD nanosuspensions are therefore not stable with time in the absence of surfactants. However, in experiments performed with surfactants (Span 80/Tween 80 ), the ethanol-dissolved CBD precipitated into NPs with size below $100 \mathrm{~nm}$ (Table 1) and there were minimal differences in NP size among fresh and 24-houraged sample. The NP size did not vary drastically while using different surfactant concentrations (Table 1).

\subsection{Morphology analysis with SEM}

CBD NPs in suspension can be synthesized by a simple precipitation reaction in the absence of surfactants, but such a suspension is not stable. Figure 1 shows the morphology of CBD NPs prepared without surfactants, where the CBD was dissolved in ethanol and precipitated with deionized water. SEM images were taken immediately after the precipitation reaction, after $24 \mathrm{~h}$ and after $96 \mathrm{~h}$. Immediately after the synthesis, the sample consisted of spherical NPs with a size of 100-350 nm (Figure 1a). Spherical NPs with a size of 100-500 nm were observed also $24 \mathrm{~h}$ after synthesis (Figure 1b). For comparison, the average NP size

Table 1: Effect of different synthesis parameters on the cannabidiol (CBD) particle size. Analysis was performed with DLS (S.D. - standard deviation; PDI - polydispersity index).

\begin{tabular}{|c|c|c|c|c|}
\hline & Fresh samples & \multicolumn{3}{|c|}{ After 24 hours } \\
\hline Parameter & Particle size $(\mathrm{nm}) \pm$ S.D. & PDI + S.D. & Particle size $(\mathrm{nm}) \pm$ S.D. & PDI + S.D. \\
\hline \multicolumn{5}{|l|}{ Solvent } \\
\hline Acetone & $817 \pm 468$ & $0.631 \pm 0.288$ & $1843 \pm 1512$ & $0.477 \pm 0.25$ \\
\hline Methanol & $557 \pm 24$ & $0.090 \pm 0.051$ & $1189 \pm 39$ & $0.105 \pm 0.036$ \\
\hline Ethanol & $700 \pm 137$ & $0.281 \pm 0.134$ & $1847 \pm 355$ & $0.214 \pm 0.080$ \\
\hline 2-propanol & $763 \pm 77$ & $0.441 \pm 0.114$ & $2621 \pm 984$ & $0.254 \pm 0.178$ \\
\hline DMSO & $832 \pm 182$ & $0.125 \pm 0.052$ & $1529 \pm 339$ & $0.244 \pm 0.033$ \\
\hline Ethylene glycol & $671 \pm 60$ & $0.185 \pm 0.032$ & $1084 \pm 78$ & $0.126 \pm 0.043$ \\
\hline \multicolumn{5}{|c|}{ Ratio of ethanol/water $(\varphi / \%)$} \\
\hline $1: 2$ & $3083 \pm 1328$ & $0.156 \pm 0.142$ & $2050 \pm 259$ & $0.476 \pm 0.422$ \\
\hline $1: 15$ & $700 \pm 137$ & $0.281 \pm 0.134$ & $1847 \pm 355$ & $0.214 \pm 0.080$ \\
\hline $1: 30$ & $533 \pm 65$ & $0.121 \pm 0.090$ & $1234 \pm 306$ & $0.225 \pm 0.086$ \\
\hline \multicolumn{5}{|c|}{ CBD concentration at ethanol/water ratio $1: 15$} \\
\hline $1 \mathrm{mg} / \mathrm{mL}$ & $550 \pm 47$ & $0.037 \pm 0.044$ & $870 \pm 69$ & $0.237 \pm 0.101$ \\
\hline $5 \mathrm{mg} / \mathrm{mL}$ & $645 \pm 50$ & $0.069 \pm 0.039$ & $1256 \pm 217$ & $0.249 \pm 0.103$ \\
\hline $10 \mathrm{mg} / \mathrm{mL}$ & $700 \pm 137$ & $0.281 \pm 0.134$ & $1847 \pm 355$ & $0.214 \pm 0.080$ \\
\hline $15 \mathrm{mg} / \mathrm{mL}$ & $706 \pm 40$ & $0.217 \pm 0.079$ & $1303 \pm 186$ & $0.434 \pm 0.088$ \\
\hline $20 \mathrm{mg} / \mathrm{mL}$ & $745 \pm 103$ & $0.552 \pm 0.073$ & $2010 \pm 325$ & $0.314 \pm 0.224$ \\
\hline \multicolumn{5}{|c|}{ Surfactant concentration at ethanol/water 1:15 } \\
\hline $0.1 \varphi / \%$ & $70 \pm 32$ & $0.452 \pm 0.082$ & $78 \pm 21$ & $0.522 \pm 0.098$ \\
\hline $0.25 \varphi / \%$ & $74 \pm 29$ & $0.781 \pm 0.145$ & $88 \pm 9$ & $0.734 \pm 0.143$ \\
\hline $0.5 \varphi / \%$ & $45 \pm 19$ & $0.866 \pm 0.110$ & $34 \pm 16$ & $0.867 \pm 0.097$ \\
\hline $0.75 \varphi / \%$ & $40 \pm 29$ & $0.946 \pm 0.060$ & $47 \pm 38$ & $0.917 \pm 0.062$ \\
\hline $1.0 \varphi / \%$ & $61 \pm 23$ & $0.878 \pm 0.084$ & $72 \pm 22$ & $0.857 \pm 0.088$ \\
\hline
\end{tabular}




\section{R. ŠTUKELJ et al.: SYNTHESIS OF STABLE CANNABIDIOL (CBD) NANOPARTICLES IN SUSPENSION}

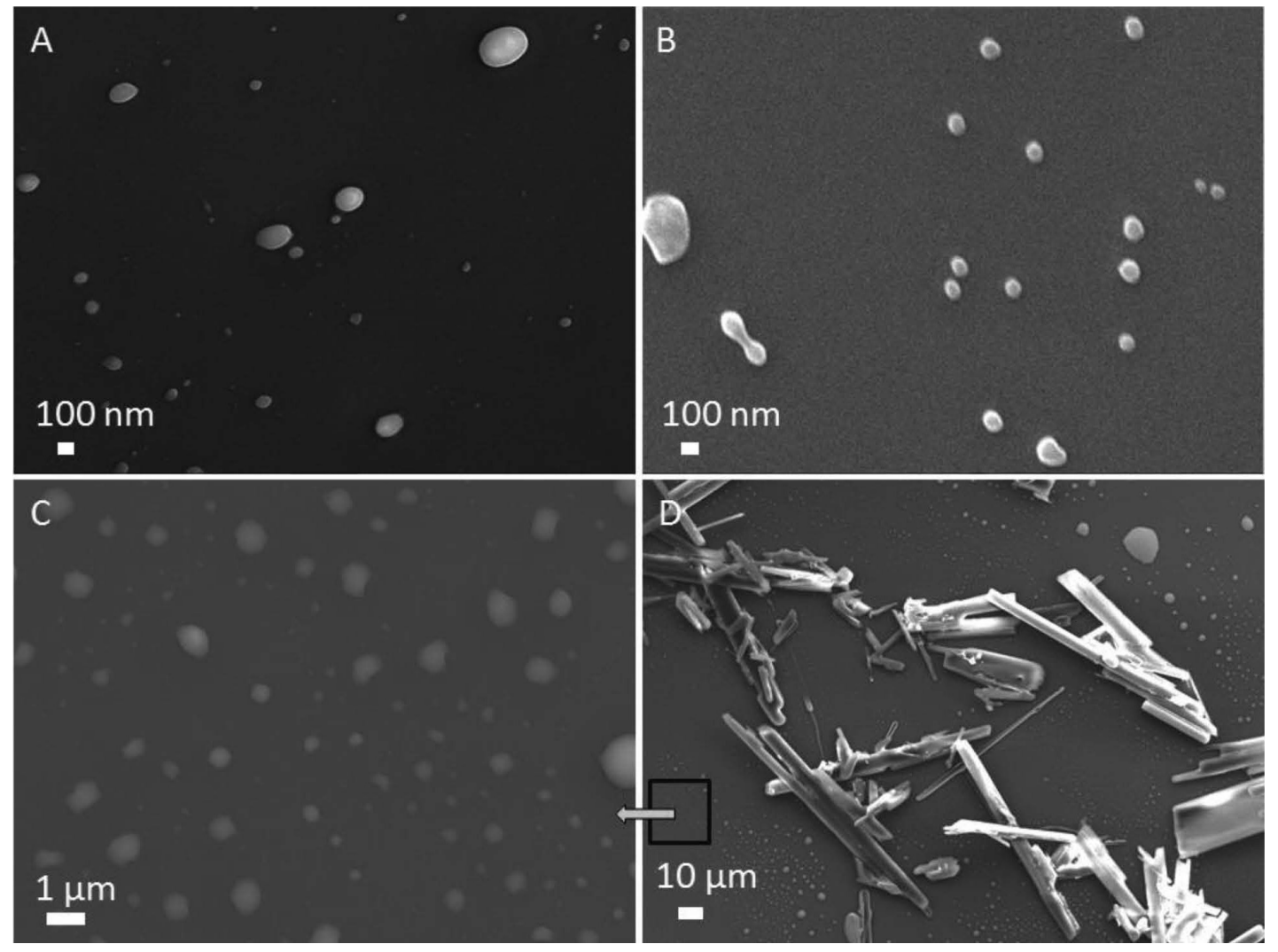

Figure 1: SEM images of CBD nanoparticles synthesized in the absence of surfactants observed a) immediately after the synthesis, b) $24 \mathrm{~h}, \mathrm{c}$ ) and d) $96 \mathrm{~h}$ after the synthesis

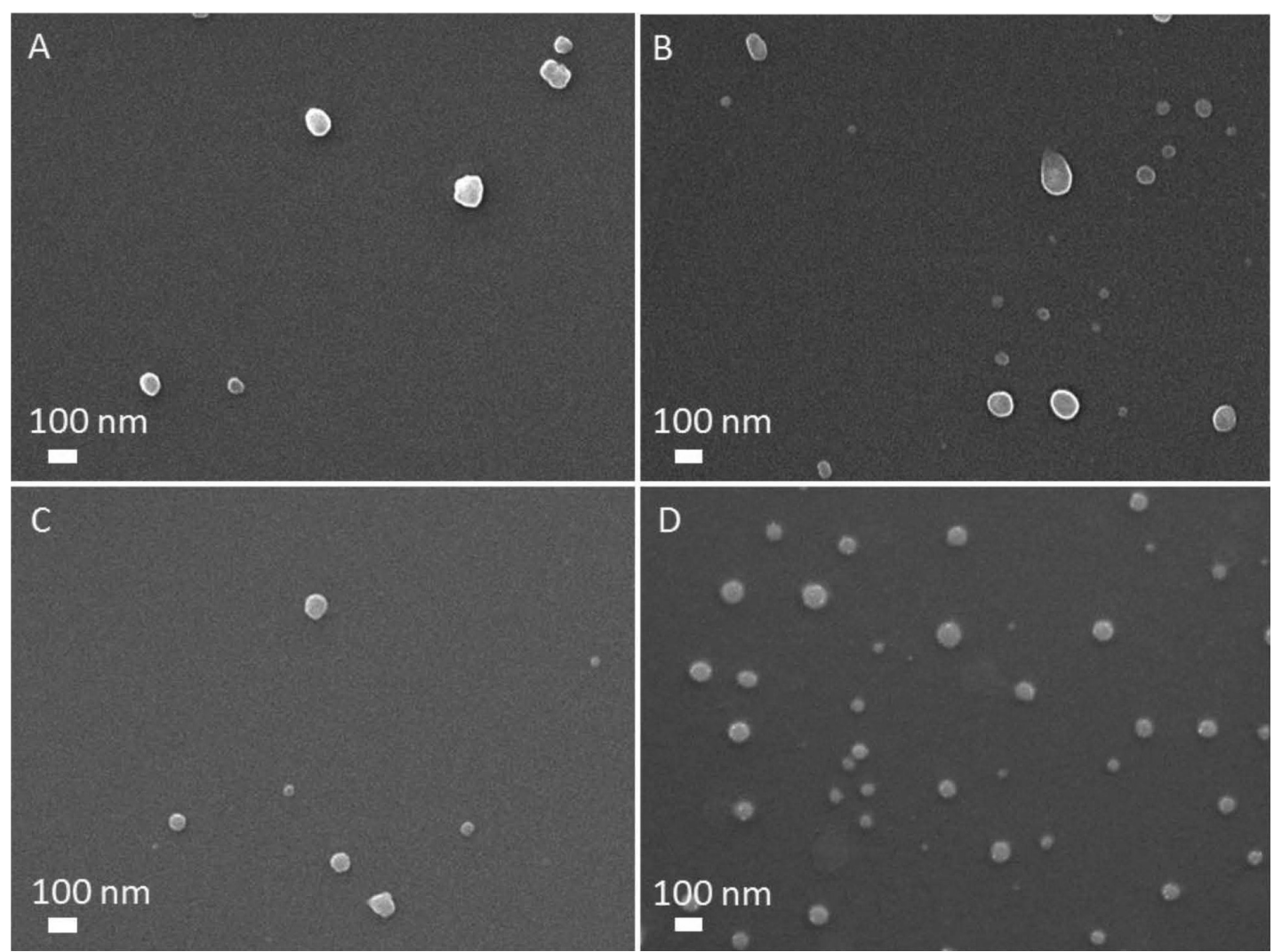

Figure 2: SEM images of CBD nanoparticles stabilized with $0.25 \%$ of surfactants observed a) immediately after the synthesis, b) $24 \mathrm{~h}$, c) $96 \mathrm{~h}$ and d) $9 \mathrm{~m}$ after the synthesis 


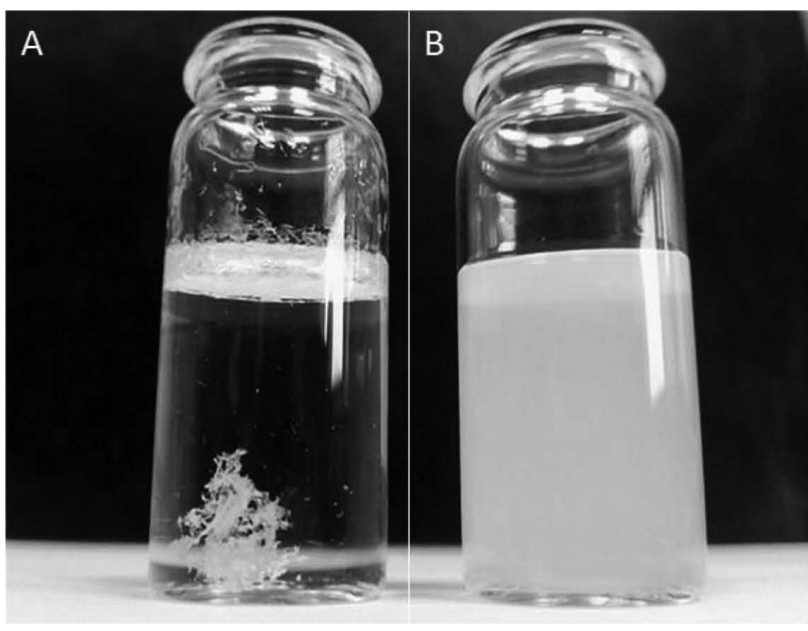

Figure 3: The difference between aged CBD suspensions: a) without surfactants and b) with surfactants; the image was taken $9 \mathrm{~m}$ after synthesis

detected with DLS measurements immediately after the synthesis was $\approx 700 \mathrm{~nm}$ and increased to $\approx 1.85 \mu \mathrm{m}$ after $24 \mathrm{~h}$, which proved agglomeration of CBD NPs in the ethanol suspension. Ninety-six hours after the synthesis, the sample mainly consisted of irregular-shaped CBD particles (Figure 1c) and elongated micro-sized particles (Figure 1d).

In order to prevent agglomeration of the CBD NPs in suspension, the mixture of Span 80/Tween 80 surfactants was added to the CBD NPs in ethanol, as presented in Table 1. The CBD NPs stabilized with $0.25 \phi / \%$ of surfactants observed immediately after synthesis, after $24 \mathrm{~h}, 96 \mathrm{~h}$ and $9 \mathrm{~m}$ (months) are presented in Figure 2. The morphology and size of the NPs in all the samples is the same - the diameter of the NPs is around $10-150 \mathrm{~nm}$. The CBD NPs in suspensions are stable even 9 months after synthesis. For comparison, the average size of NPs stabilized with $0.25 \phi / \%$ of surfactants is around $50 \mathrm{~nm}$ according to the DLS measurements.

The agglomeration of CBD nanoparticles in suspension without surfactants can be observed with the naked eye $96 \mathrm{~h}$ after the synthesis, as presented in Figure 3a. In contrast, the suspension with surfactants remains stable even after $9 \mathrm{~m}$ (Figure $3 \mathbf{b}$ ).

\section{DISCUSSION}

Cannabinoids are considered to be highly hydrophobic lipids, almost insoluble in water, but highly soluble in organic solvents. Low aqueous solubility of cannabinoids is correlated with low bioavailability of these drugs and represents a major drawback to their therapeutic effectiveness. Nanonization is a simple and effective method to improve the dissolution rate and bioavailability of drugs; however, the agglomeration of nanoparticles in solutions presents additional problems for the formations of stable nanosuspensions. ${ }^{44}$ Therefore, bio- nanoparticles are often encapsulated with polymers, ${ }^{45}$ self-assembling peptide hydrogels, ${ }^{46}$ alginate-chitosanpluronic composites,${ }^{47}$ etc. Yadav and Kumar reported on curcumin nanonization with $0.5 \%$ gelatin as a stabilizer; such a suspension remained stable for up to $3 \mathrm{~h}^{48}$ Winnincki claims that a THC aqueous micelle suspension containing guar gum was stable for $7 \mathrm{~d}$ (days), while the aqueous liposomal suspension was stable for more than $3 \mathrm{~m}^{49}$

In this contribution, the average NP size determined with DLS measurements immediately after the synthesis was $\approx 700 \mathrm{~nm}$ and this increased to $\approx 1850 \mathrm{~nm}$ after $24 \mathrm{~h}$. Agglomeration of the CBD NPs was confirmed also with SEM analysis. However, the CBD nanosuspensions were stable for $9 \mathrm{~m}$ with the addition of surfactants. It is expected that as-synthesized CBD NPs could be more bioavailable. Further studies are required in order to evaluate the bioavailability of the CBD NPs.

\section{CONCLUSIONS}

Cannabinoids are attracting increasing attention in medicine and the food industry due to their outstanding properties and versatile potential applications. The major drawbacks of cannabinoids are poor absorption and bioavailability, which could be increased with the nanonization of these compounds. However, the preparation of stable NP suspensions is challenging due to their tendency for agglomeration. In the present research, suspensions of CBD NPs were synthesized by a simple precipitation reaction. The average size of CBD NPs was around $50 \mathrm{~nm}$ immediately after the preparation, but increased with time due to agglomeration. The addition of surfactants conserved the average size of the CBD NPs up to $9 \mathrm{~m}$.

\section{Acknowledgment}

This work was supported by the Slovenian Research Agency (ARRS) grants P3-0388, P2-0377, J5-7098, J2-8166, J2-8169 and L7-7566. The authors would like to acknowledge Pharmahemp d.o.o., Slovenia, for providing the cannabidiol crystal isolate.

\section{REFERENCES}

${ }^{1}$ M. A. ElSohly, D. Slade, Chemical constituents of marijuana: the complex mixture of natural cannabinoids, Life sci., 8 (2005), 539-548, doi:10.1016/j.lfs.2005.09.011

${ }^{2}$ J. M. McPartland, E. B. Russo, Cannabis and cannabis extracts: greater than the sum of their parts, J Cannabis Therapeutics., 1 (2001), 103-132, doi:10.1300/J175v01n03_08

${ }^{3}$ C. M. Andre, J. F. Hausman, Guerriero G.: Cannabis sativa: the plant of the thousand and one molecules, Front. Plant Sci., 7 (2016) 19 , doi:10.3389/fpls.2016.00019

${ }^{4}$ R. Brenneisen, Chemistry and analysis of phytocannabinoids and other Cannabis constituents, Marijuana and the Cannabinoids, Springer, 2007, 17-49 


\section{R. ŠTUKELJ et al.: SYNTHESIS OF STABLE CANNABIDIOL (CBD) NANOPARTICLES IN SUSPENSION}

${ }^{5}$ R. Mechoulam, Y. Gaoni, Recent advances in the chemistry of hashish, Fortschritte der Chemie Organischer Naturstoffe/Progress in the Chemistry of Organic Natural Products/Progrès dans la Chimie des Substances Organiques Naturelles, Springer, 1967, 175-213

${ }^{6} \mathrm{~A}$. Mead, The legal status of cannabis (marijuana) and cannabidiol (CBD) under US law, Epilepsy Behav., 70 (2017), 288-291, doi:10.1016/j.yebeh.2016.11.021

${ }^{7}$ E. B. Russo, Taming THC: potential cannabis synergy and phytocannabinoid-terpenoid entourage effects, Br. J. Clin. Pharmacol., 163 (2011), 1344-1364, doi:10.1111/j.1476-5381.2011.01238.x

${ }^{8}$ P. F. Whiting, R. F. Wolff, S. Deshpande, M. Di Nisio, S. Duffy, A. V. Hernandez, C. Keurentjes, S. Lang, K. Misso, S. Ryder et al., Cannabinoids for medical use: a systematic review and metaanalysis, Jama., 313 (2015), 2456-2473, doi:10.1001/jama. 2015.6358

${ }^{9}$ O. Devinsky, E. Marsh, D. Friedman, E. Thiele, L. Laux, J. Sullivan, D. Miller, R. Flamini, A. Wilfong, F. Filloux et al., Cannabidiol in patients with treatment-resistant epilepsy: an open-label interventional trial, Lancet Neurol., 15 (2016), 270-278, doi:10.1016/ S1474-4422(15)00379-8

${ }^{10}$ E. J. Hess, K. A. Moody, A. L. Geffrey, S. F. Pollack, L. A. Skirvin, P. L. Bruno, J. L. Paolini, E. A. Thiele, Cannabidiol as a new treatment for drug-resistant epilepsy in tuberous sclerosis complex, Epilepsia., 57 (2016), 1617-2164, doi:10.1111/epi.13499

${ }^{11}$ C. A. Press, K. G. Knupp, K. E Chapman, Parental reporting of response to oral cannabis extracts for treatment of refractory epilepsy, Epilepsy Behav., 45 (2015), 49-52, doi:10.1016/j.yebeh.2015.02.043

${ }^{12}$ D. S. Reddy, V. M. Golub, The pharmacological basis of cannabis therapy for epilepsy, J. Pharmacol. Exp. Ther., 357 (2016), 45-55, doi:10.1124/jpet.115.230151

${ }^{13}$ P. Consroe, R. Sandyk, S. R. Snider, Open label evaluation of cannabidiol in dystonic movement disorders, Int. J. Neurosci., 30 (1986), 277-282

${ }^{14}$ K. Müller-Vahl, H. Kolbe, U. Schneider, H. M. Emrich, Cannabis in movement disorders, Compl. Med. Res., 3 (1999), 23-27

${ }^{15}$ E. M. Blessing, M. M. Steenkamp, J. Manzanares, C. R. Marmar, Cannabidiol as a potential treatment for anxiety disorders, Neurotherapeutics., 12 (2015), 825-836, doi:10.1007/s13311-015-0387-1

${ }^{16}$ E. M. Williamson, F. J. Evans, Cannabinoids in clinical practice, Drugs, 60 (2000), 1303-1314, doi:10.2165/00003495-20006006000005

${ }^{17}$ A. W Zuardi, Cannabidiol: from an inactive cannabinoid to a drug with wide spectrum of action, Rev. Bras. Psiquiatr., 30 (2008), 271-280, doi:10.1590/S1516-44462008000300015

${ }^{18}$ S. Burstein, Cannabidiol (CBD) and its analogs: a review of their effects on inflammation, Bioorg. Med. Chem., 23 (2015), 1377-1385, doi:10.1016/j.bmc.2015.01.059

${ }^{19}$ P. Nagarkatti, R. Pandey, S. A. Rieder, V. L. Hegde, M. Nagarkatti, Cannabinoids as novel anti-inflammatory drugs, Future Med. Chem., 1 (2009), 1333-1349, doi:10.4155/fmc.09.93

${ }^{20}$ L. A. Parker, E. M. Rock, C. L. Limebeer, Regulation of nausea and vomiting by cannabinoids, Br. J. Clin. Pharmacol., 163 (2011), 1411-1422, doi:10.1111/j.1476-5381.2010.01176.x

${ }^{21}$ A. W. Zuardi, J. A. Crippa, J. E. C. Hallak, S. Bhattacharyya, Z. Atakan, R. Martín-Santos, P. K. McGuire, F. S. Guimarães, A critical review of the antipsychotic effects of cannabidiol: 30 years of a translational investigation, Curr. Pharm. Des., 18 (2012), 5131-5140, doi: $10.2174 / 138161212802884681$

${ }^{22}$ A. Hampson, M. Grimaldi, J. Axelrod, D. Wink, Cannabidiol and (-) $\Delta$ 9-tetrahydrocannabinol are neuroprotective antioxidants, Proc. Natl. Acad. Sci., 95 (1998), 8268-8273, doi:10.1073/pnas.95.14.8268 ${ }^{23}$ K. Hayakawa, K. Mishima, M. Fujiwara, Therapeutic potential of non-psychotropic cannabidiol in ischemic stroke, Pharmaceuticals, 3 (2010), 2197-2212, doi:10.3390/ph3072197

${ }^{24}$ R. Adams, H. Wolff, D. C. Pease, C. K. Cain, R. B. Wearn, R. B. Baker, H. Wolff, Structure of Cannabidiol. V. 1 Position of the Alicyclic Double Bonds, J. Am. Chem. Soc., 62 (1940), 2215-2219
${ }^{25}$ R. Mechoulam, Y. Shvo, Hashish-I: The structure of Cannabidiol, Tetrahedron, 19 (1963), 2073-2078, doi:10.1016/0040-4020(63) 85022-X

${ }^{26}$ Z. Atakan, Cannabis, a complex plant: different compounds and different effects on individuals, Ther. Adv. Psychopharmacol., 2 (2012), 241-254, doi:10.1177/2045125312457586

${ }^{27}$ R. G. Pertwee, Cannabinoid pharmacology: the first 66 years, Br. J. Clin. Pharmacol., (2006) 147, doi:10.1038/sj.bjp.0706406

${ }^{28}$ M. Guzman, Cannabinoids: potential anticancer agents, Nat. Rev. Cancer., 3 (2003) 745, doi:10.1038/nrc1188

${ }^{29}$ R. Smith, C. Vaughan, The decomposition of acidic and neutral cannabinoids in organic solvents, J. Pharm. Pharmacol., 29 (1977), 286-290

${ }^{30}$ L. A. Matsuda, S. J. Lolait, M. J. Brownstein, A. C. Young, T. I. Bonner, Structure of a cannabinoid receptor and functional expression of the cloned cDNA, Nature, 346 (1990), 561, doi:10.1038/ $346561 \mathrm{a} 0$

${ }^{31}$ K. Mackie, Cannabinoid receptors: where they are and what they do, J. neuroendocrinol., 20 (2008) 10-14, doi:10.1111/j.1365-2826.2008. 01671.x

${ }^{32}$ C. Lipinski, Poor aqueous solubility-an industry wide problem in drug discovery, Am. Pharm. Rev., 5 (2002), 82-85

${ }^{33}$ M. A. Huestis, Human cannabinoid pharmacokinetics, Chem. Biodivers., 4 (2007), 1770-1804, doi:10.1002/cbdv.200790152

${ }^{34}$ H. Devalapally, A. Chakilam, M. M. Amiji, Role of nanotechnology in pharmaceutical product development, J. Pharm. Sci., 96 (2007), 2547-2565, doi:10.1002/jps.20875

${ }^{35}$ J. U. A. Junghanns, R. H. Müller, Nanocrystal technology, drug delivery and clinical applications, Int. J. Nanomedicine, 3 (2008), 295, doi:10.2147/IJN.S595

${ }^{36}$ D. Yadav, N. Kumar, Nanonization of curcumin by antisolvent precipitation: process development, characterization, freeze drying and stability performance, Int. J. Nanomedicine, 477 (2014), 564-577, doi:10.1016/j.ijpharm.2014.10.070

${ }^{37}$ M. Gera, N. Sharma, M. Ghosh, D. L. Huynh, S. J. Lee, T. Min, T. Kwon, D. K. Jeong, Nanoformulations of curcumin: an emerging paradigm for improved remedial application, Oncotarget., 8 (2017), 66680, doi:10.18632/oncotarget.19164

${ }^{38}$ F. L. Yen, T. H. Wu, C. W. Tzeng, L. T. Lin, C. C. Lin, Curcumin nanoparticles improve the physicochemical properties of curcumin and effectively enhance its antioxidant and antihepatoma activities, J Agric. Food. Chem., 58 (2010), 7376-7382, doi:10.1021/jf100135h

${ }^{39}$ H. Heinz, C. Pramanik, O. Heinz, Y. Ding, R. K. Mishra, D. Marchon et al., Nanoparticle decoration with surfactants: molecular interactions, assembly, and applications, Surf. Sci. Rep., 72 (2017), 1-58, doi:10.1016/j.surfrep.2017.02.001

${ }^{40} \mathrm{~S}$. M. Morsy, Role of surfactants in nanotechnology and their applications. Int. J. Curr. Microbiol. App. Sci, 3 (2014), 237-260

${ }^{41}$ M. M. Amiji, Nanotechnology for cancer therapy, CRC press, 2006

${ }^{42}$ B. S. Sekhon, Surfactants: Pharmaceutical and medicinal aspects. JAPTR, 1 (2013), 11-36, doi:10.15415/jptrm.2013.11004

${ }^{43}$ J. Breitkreutz, C. Tuleu, Pediatric and geriatric pharmaceutics and formulation, Modern Pharmaceutics, 2009, 221-258

${ }^{44}$ H. Chen, C. Khemtong, X. Yang, X. Chang, J. Gao, Nanonization strategies for poorly water-soluble drugs, Drug. discov. today., 16 (2011), 354-360, doi:10.1016/j.drudis.2010.02.00

${ }^{45}$ J. R. R. Amado, A. L. Prada, J. B. Duarte, H. Keita, H. Rivero da Silva, A. M. Ferreira, E. H. Sosa, J. C. T. Carvalho, Development, stability and in vitro delivery profile of new loratadine-loaded nanoparticles, Saudi Pharm. J., 25 (2017), 1158-1168, doi:10.1016/ j.jsps.2017.07.008

${ }^{46}$ H. Shen, X. Hu, M. Szymusiak, Z. J. Wang, Y. Liu, Orally administered nanocurcumin to attenuate morphine tolerance: comparison between negatively charged PLGA and partially and fully PEGylated nanoparticles, Mol. Pharm., 10 (2013), 4546-4551, doi:10.1021/mp400358z 


\section{R. ŠTUKELJ et al.: SYNTHESIS OF STABLE CANNABIDIOL (CBD) NANOPARTICLES IN SUSPENSION}

${ }^{47}$ A. Altunbas, S.J. Lee, S. A. Rajasekaran, J.P. Schneider, D.J. Pochan, Encapsulation of curcumin in self-assembling peptide hydrogels as injectable drug delivery vehicles, Biomaterials, 32 (2011), 5906-5914, doi:10.1016/j.biomaterials.2011.04.069

${ }^{48}$ R. K. Das, N. Kasoju, U. Bora, Encapsulation of curcumin in alginate-chitosan-pluronic composite nanoparticles for delivery to cancer cells, Nanomedicine, 6 (2010), 153-160, doi:10.1016/j.nano.2009. 05.009

${ }^{49} \mathrm{R}$. Winnicki, Cannabinoid formulations, US8808734B2, priority date: 2011.07.11. Google Patents, 2015 